Yellow; when formaldehyde gas strikes this paper, the yellow color turns violet. I mixed 112 minims of formalin-45 ininims of pure formaldehyde-with 2 ounces of warm normal salt solution; a vein was picked up in a dog's foreleg and the solution was slowly transfused; the yellow-colored blotting laper was immediatcly held near the dog's mouth; the violet color appcared in a few seconds. Of course, the dog died in two or three minutes, but the second proposition was solvedthe gas escaped by the mouth. On the second dog, I used 25 minims formalin- 10 minims pure formaldehyde. On a third (log, I used 37 minims formalin-15 minims pure formaldehyde. These two dogs lived and seemed as well aftcr the experiments as before. In these, also, the formaldehyde escaped by the mouth. The yellow colored blotting paper gave no reaction of the formaldehyde test when arterial blood from the dead $\operatorname{dog}$ was heated.

E. VIKo, M.D.

The Philadelphia Medical Journal.

Philladel,phia, Jan. 22, 1901.

T'o the Editor:-The issue of The Journal for January 5 rontained statements which might convey a wrong impression coneerning the changes recently made in the Philadelphia Merlical Journal, its financial strength, the chances of its continued success and the nature of its aims as an exponent of high professional ethics. The insertion of this letter in your columns would therefore be greatly appreciated.

The changes recently made in the editorial department were based upon the action of a board of trustees, which contained at the time, as it does now, a proportion of five physicians to every lay member. That the Journal has. and will continue to be inspired by men who are familiar with "high ideals in medicine" and the needs of the general profession is therefore evident. True, the shareholders have not as yet received dividends. This is due to the fact that they have "sunk a large "mount of money" in the elaboration of a foundation as enduring as the original plan of the Philadelphia Medical Journal was comprehensive. This was not done through the "lack of sagacity of those who put their money into it." but in order to better serve its subscribers and merit their continued patronage-the secret of success. Indeed, never has the ethical, scientific and finsncial position of the Philadelphia Medical Journal been more secure than at the present time; and, far from having "a demoralizing effect on legitimate medical jour. nalism," it will continue, with its old contemporaries, especially' The Journal of the Ayerican Medical Association, in its efforts to maintain the dignity, honor and seientific standard of American medicinc. Your truly,

JohN B. Roberts. M.D., Secretary.

13. Order of the Board of Trustees.

\section{The Association's 1902 Meeting.}

Memphis, Tenn., Jan. 22, 1901.

'To the Editor:-The 1902 meeting of the American Medical Association should logically come south. Other southern cities, Atlanta, New Orleans, Louisville and Nashville have been honored, and Memphis is now the third largest city south of the Ohio River, with a population, by the U. S. census of 1900 , of 102,320. It is well and centrally located, being in the very heart of the great Mississippi Valley. We have also eleven trunk lines, making Memphis accessible from all points. Besides, the adjacent territory, Mississippi, Alabama, Arkansas. Tennessee, Louisiana, Texas and southeast Missouri has many good physicians who have never joined the AMERICAN MEDICAL Association. I believe that if Memphis could secure the meeting next year our membership would be materially increased. Some few have doubted our ability to entertain the Association, but we now have in course of construction one of the finest hotels in the South, and our hotel facilities in general will be ample to accommodate all who may be present. With reference to suitable halls for the various sections, I can safely say there will be no trouble in securing all we need. We have a large auditorium, with a seating capacity of 4500 , which would serve well for the general sessions, also for exhibits. and May would be the ideal month for the meeting should it come south. Our business men are liberal and progressive and it is safe to say that the Merchants' Exchange will do its part. Let the American Medical Association come south in 1902, to Memphis, the Queen City of the Missis. sippi Valley. Respectfully, Frank A. Jones, M.D.

\section{Incised Wounds.}

Chicago, tan. 28, 1901.

To the Editor:-In regard to abstract No. 121 , in the Jan. uary 19 issue of The JoUnNal (p. 216) I wish to say, without criticizing the author, that $I$ have been using that method ever since it was shown me by Dr. J. A. McDonell, of this city, and it was not original with him. As early as July, 1872, while Dr. MeDonell was practicing in Boston, N. Y., an old shoemaker, named Silas Root, witnessed the Doctor trying to sew up an incised wound in a child, and as the child cried from pain this old shoemaker said: "Let me show how to coapt those edges without causing the child any pain." He thereupon took two pieces of shoeleather, shaved the rough parts off, punched holes in the approximating edges and then, by means of shoemaker's wax, attached these two pieces of leather to the skin on each side of the wound, and then laced them together with ordinary fine twine. Union was complete, and Dr. McDonell was so pleased with the result that this method became routine with him in all incised wounds. Later when adhesive plaster was put on the market, Dr. McDonell began to use that, approximating the free edges with a sterilized needle and linen thread, and this is now his routine and has been since the introduction of adhesive plaster.

331 Loomis Street.

BenJ. H. Breakstone, M.1).

\section{The British Pharmacopeia.}

Ashton, R. I., Jan. 21, 1901.

T', the E'ditor:-In The Journal of January 19, your LonIon correspondent speaking of the British Pharmacopeia states that there were converted into this three pharmacopeias in the United Kingdom, issued by the Colleges of Physicians of London, Edinburgh and Glasgow respectively.

Now. in a great organ of professional thought and action like THE JockNAI its readers expect above all things accuracy. There are, undoubtedly, in the United Kingdom three colleges of physicians, one for each kingdom, in London, Edinburgh and Dublin.

Your correspondent robs Treland, giving Scotland double her due. N. O'N. PARIKS, I. C. P. I.

\section{Marriages.}

W. If. Raysey, M.J), Omaha. Neb.. to Miss Edna Ball, Waco, Texas. January 16.

Euward B. Evans, M.D., Fargo, N. Dak. to Miss Jennie lind Lewis, January 13.

Nelson M. Black, M.D., to Miss Erna Leidersdorf, both of Milwaukee. Wis., January 22.

Fraxk E. Donelan, M.D., Glenwood, Iowa. to Miss Winifred Wells. Tabor, Iowa, January 13.

Chanles R. Grandy, M.D. Norfolk, Va.. to Miss Mabel Dickman. Richmond. Va.. January 17.

Jediafr H. Crark, M.D., Richmond, Ind.. to Miss Anna Hessler, Connersville, Ind., January 1.

Axirew Ekern, M.D., Grand Forks, N. Dak., to Miss Signa Hustmark, Seattle, Wash., January 16.

Frayk Mrllakd Severson, M.D., Seneca Falls, N. Y.. to Miss Anna Evelyn Mead, Chicago, January 16.

\section{Deaths and Dbituaries.}

William D. Haggard, Sr., died at Columbia, Tenn., January 25, from the effects of a stroke of paralysis which occurred the previous day. He was born in Kentucky, 74 years ago, and his ambition from boyhood was to be a physician. 